\title{
Anticoccidial Activity of Artemisinin and Extract of Artemesia annua Leaves in Chicken Infected by Eimeria tenella
}

\author{
Wiedosari E, Wardhana $\mathrm{AH}$ \\ Indonesian Research Center for Veterinary Sciences \\ E-mail: eningwied@yahoo.com
}

(receiced: 05-10-2017; revised: 16-11-2017; accepted 20-12-2017)

\begin{abstract}
ABSTRAK
Wiedosari E, Wardhana AH. 2017. Aktivitas antikoksidia artemisinin dan ekstrak daun Artemesia annua pada ayam yang diinfeksi dengan Eimeria tenella. JITV 22(4): 196-204. DOI: http://dx.doi.org/10.14334/jitv.v22i4.1622

Penggunaan antikoksidia pada ayam yang terus menerus telah memicu timbulnya resistensi obat dan residu dalam jaringan, sehingga perlu dicari obat alternatif yang berbasis herbal. Tujuan penelitian ini adalah untuk menguji aktivitas antikoksidia artemisinin dan ekstrak daun Artemesia annua pada ayam yang diinfeksi dengan Eimeria tenella. Sebanyak 35 ayam jantan strain Cobb dibagi menjadi tujuh perlakuan dengan lima ulangan, yaitu kelompok ayam normal (P I), diinfeksi tanpa pengobatan (P II), diinfeksi dan diobati dengan 8,5 ppm, 17 ppm, 34 ppm masing-masing untuk P III, P IV dan P V, diinfeksi dan diobati dengan 17 ppm ekstrak daun A. апnиа (P VI) dan diinfeksi dan diobati dengan Sulfa (P VII). Setiap ayam diinfeksi dengan $E$. tenella dosis rendah, yaitu 2000 ookista kecuali kelompok ayam normal. Pengobatan dilakukan setiap hari selama delapan hari secara oral. Variabel yang diamati adalah gejala klinis, jumlah ookista dalam feses, pertambahan bobot badan, skor perlukaan sekum, nilai hematokrit (PCV) dan hemoglobin (Hb). Hasil penelitian menunjukkan bahwa pemberian 17 ppm ekstrak daun $A$. аппиа (P VI) paling efektif dalam menurunkan jumlah ookista $(74,18 \%)$ diikuti dengan perlakuan 34 ppm artemisinin $(58,14 \%)$. Ekstrak daun $A$. апnиa dan artemisinin juga mampu mengurangi perlukaan sekum secara nyata $(\mathrm{P}<0,05)$. Walaupun pertambahan bobot badan dan nilai Hb juga tidak menunjukkan perbedaan yang nyata pada semua perlakuan $(\mathrm{P}>0,05)$, tetapi pemberian artemisinin dan ekstrak daun A. annua mampu mempertahankan nilai PCV secara nyata dibandingkan P II dan P IV $(\mathrm{p}<0,05)$ sehingga dapat digunakan sebagai antikoksidia alternatif untuk ayam.
\end{abstract}

Kata kunci: Eimeria tenella, Artemisinin, Artemesia annua, Koksidiosis

\begin{abstract}
Wiedosari E, Wardhana AH. 2017. Anticoccidial activity of Artemisinin and Extract of Artemesia annua leaves in chicken infected by Eimeria tenella. JITV 22(4): 196-204. DOI: http://dx.doi.org/10.14334/jitv.v22i4.1622

The continuous use of anticoccidial drug in chicken often continuously generates drug resistance and tissue residue; so thatconsequently, a safe alternative anticoccidial drug based on herb is fundamentally required. The aim of thise study was to examine anticcocidial activity of artemisinin and extract of Artemesia annua leaves in chicken infected by Eimeria tenella. A total of 35 chickens of Cobb strain was divided into seven groups with five replicates birds per group, i.e. uninfected chicken group (P I), infected but untreated chicken group (P II), infected and treated chicken group with $8.5 \mathrm{ppm}, 17 \mathrm{ppm}, 34 \mathrm{ppm}$, for P III, P IV and P V respectively, infected and treated chicken with $17 \mathrm{ppm}$ of A. annua extract (P VI) and infected and treated chicken with Sulfa (P VII). All chicken, except the uninfected group, whereas infected with 2000 infective oocyst of E. tenella except the uninfected group. Treatment was delivered by oral, once per day for eight days. The criteria observed were clinical manifestation of chickens, number of oocyst in feces, body weight, cecal lesion score, haematocrit (packed cell volume) and haemoglobin value. The results showed that extract of $A$. annua leaves (P VI) was the most effective treatment to reduce the number of oocyst in feces (74.18\%), followed by $34 \mathrm{ppm}$ of artemisinin group (P VII). In addition, application of $A$. annua extract and artemisinin was significantly able to decreased the cecal lesion score $(\mathrm{P}<0.05)$. Even though body weight and $\mathrm{Hb}$ value were not indifferent significantly different $(\mathrm{p}>0.05)$, however $A$. апnиa extract and artemisinin treatments were significantly able to hold PCV value on normal level compared to P II and P IV $(\mathrm{P}<0.05)$. It concluded that extract $A$. annua leaves and artemisinin could be used an alternative anticoccidial in chickens.
\end{abstract}

Key Words: Eimeria tenella, Artemisinin, Artemesia annua, Coccidiosis

\section{INTRODUCTION}

Coccidiosis in chicken remains a major problem in poultry industry in Indonesia and many other countries.
This disease is caused by intracellular protozoa, Eimeria spp, which is highly pathogen and able to multiply at 21 $-32^{\circ} \mathrm{C}$ and $75-85 \%$ humidity. Infection of the E. tenella in poultry injures intestinal mucosae which results in 
decreases nutrient absorbtion and feed eficiency, and increase secondary bacteria infection (Morris et al. 2007; Cooper \& Songer 2009). Adamu et al. (2013) showed that E. tenella infection in chicken caused decreases in hematocryte (packed cell volume, PCV) and hemaglobin $(\mathrm{Hb})$ that led to the enamia. The annual economic loss caused by the disease is estimated to be 1.5 billion US dollars in the United States alone, or 3 billion US dollaarrs worldwide (Dalloul \& Lillehoj 2006; Lee et al. 2009). Tresnani et al. (2012) reported that the morbidity of coccidiosis in Indonesia was 80 $90 \%$ with the loss reached $70 \%$ consisting of decrease body weight, delay in laying, decrease egg production, and decrease in feed efficiency, incraese operational cost (Dalloul \& Lillehoj 2006; Wiedosari et al. 2014).

So far, the control of coccidiosis relys on coccidiostate of sophonamide group such as sulfaquinoxalin, sulfadimetoxin, amprolium and decoquinate (Tabbu 2006). However, intensive use of the coccidiostate in the feed reported to induces resistance to E. tenella and coccidiostate residue in the poultry products (El-Sadawy et al. 2009; Kheirabadi et al. 2014). This problem could be overcome by rotating the use of coccidiostate with different active substances. Unfortunately, this strategy will raise the production cost of the poultry industrial, and therefore this strategy is rarely used (Abbas et al. 2010). Herbal-based-anti coccidia are an attractive analternative because it does not leave residue in the products or induce resistance to the protozoa. In addition, herbal-based-anti coccidia is compatible for the medication of sub clinical infection or infection with low number of E. tenella (Habibi et al. 2016).

Plant of the Artemisia genus was reported to have antiprotozoa activities (Aryanti et al. 2006; del Cacho et al. 2010). The use of A. Sieberi was reported effective for E. tenella and E. acervulina but not for E. maxima (Arab et al. 2006). Compared to the A. sieberi, A. annua is available more abundantly, and had been used widely for treatment many parasitic diseases. Artemisia annua contains complex terpenoid compounds, including sesquiterpenes lactone compounds known as artemisinin. This plant has been used as an alternative treatment for malaria and in addition it has antibacterial, anti-protozoa anti-inflammatory, and antitumor activities (Ferreira et al. 2011). A methanol exctract of the A. аnпиa leaf and its powder proved to ehance humoral and cellular immune system of broiler chickens (Gholamrezaie et al. 2013). Synthetic artemisinin at $17 \mathrm{ppm}$ concentrations was able to block the formation of ookista walls and prevent the occurrence of E. tenella sporulation (del Cacho et al. 2010). Addition of $20 \%$ powdered leaf of A. апnиа in feed was reported to increase egg production and the colour intensity of the yolk (Brisibe et al. 2008).
(Drăgan et al. 2014) found that the effectiveness of herbal-based anticoxidia is influenced by several factors such as plant parts used, seasonal variations, herbal drying methods, herbal concentrations, strain and dose of E. tenella, application route of anticoxidia, poultry strains. The A-annua leaves dried air-dried- have higher artemisinin content than freeze- dried- methods (Ferreira \& Luthria 2010). The objective of this study was to investigate the antikoksidia activity of synthetic artemisinin and A. апnиa leaf extract in Cobb strain chicken infected with E. tenella of local isolate at low doses or sub-clinical infections.

\section{MATERIALS AND METHODS}

\section{Plant collection and extraction}

Leaves of A. апnиa was obtained from the Indonesian Spice and Medicinal Crops Research Institute (BALITTRO) at Lembang, West Java. The leaves were dried at room temperature for 1 week.

The leaves were first macerated, and as much as 300 grams of the leaf powder was soaked in $3 \mathrm{~L}$ petroleum ether in Erlemeyer and agitated for 2 hours. The petroleum ether solution that contained the active compound was filtered and evaporated. The A. аппиа leaf extracts which appered as thickly paste was stored in $4^{\circ} \mathrm{C}$ until used.

\section{Artemisinin}

Synthetic artemisinin used in this study was Artemisinin $99 \%$ powder (parchem). Artemisinin powder was dissolved in sterile distilled water until used.

\section{Experimental animal}

Day old Cobb broiler chicks were kept in a cage that previously had been decontaminated with potassium permanganate $\left(\mathrm{KMnO}_{4}\right)$ and $40 \%$ formalin solution at a ratio of $1: 2$. Vaccination against New castle disease was given when the chicks was at 1 week old. The birds are fed on pelleted ration that did not contain any coccidiostat. Drinking water was given ad libitum.

\section{Isolation and propagation of $E$. tenella}

Eimeria tenella used in this study was isolated from infected chicken in Sukabumi. The contents of the cecum were removed, suspended in solution of Sheather sugar, filtered and carified by centrifugation. The presence of oocysts in the supernatant was examined under a microscope. The E. tenella, after confirmed by its morphology and size was isolated. The parasites 
were passaged in six days old, free-coccidia chicks. The oocysts were put into a Petri dish, potassium bichromate $(\mathrm{K} 2 \mathrm{Cr} 2 \mathrm{O} 7)$ at a concentration of $2.5 \%$ was added, and incubated at room temperature for three days in a slightly opened Petri dish. Sporulated oocysts were used to infect by experimental chickens (Jiang et al. 2012; Khaier et al. 2015).

\section{E. tenella infection}

Prior to experimental infection, the oocysts were washed in distilled water and inoculated orally to chicken at a dose of 2000 sporulated oocysts per bird. The chickens were put into a cage based on the treatment group. Clinical symptoms and the occurrence of blood defecation observed until day eight.

\section{Treatment}

Thirty five chickens were divided into 7 groups, 5 birds/ group. Following was the groups and treatment applied:

$\begin{array}{lll}\text { PI } & : & \text { Uninfected } \\ \text { PII } & : & \text { Infected but untreated } \\ \text { PIII } & : & \begin{array}{l}\text { Infected and treated with } 8.5 \mathrm{ppm} \text { of } \\ \text { arteminisin powder }\end{array} \\ \text { PIV } \quad: & \begin{array}{l}\text { Infected and treated with } 17 \mathrm{ppm} \text { of } \\ \text { arteminisin powder }\end{array} \\ \text { PV } \quad: \quad \begin{array}{l}\text { Infected and treated with } 34 \mathrm{ppm} \text { of } \\ \text { arteminisin powder }\end{array} \\ \text { PVI } \quad: \begin{array}{l}\text { Infected and treated with17 } \mathrm{ppm} \text { of } A . \\ \text { annua leaf extract } \\ \text { PVII } \quad:\end{array} \\ \end{array}$

The treatments were performed once a day since the first day after $E$. tenella infection orally for eight days.

\section{Observation of caeca lesion}

Necroption was performed eight days after infection. All abnormalities on the cecum were recorded and the damage on the mucosal surface was scored, from scor 0 to 4 (Tabbu 2006). Score 0 was for normal or no lesion; score 1 was mild lesion, ptechiae spread on the surface of the caecal mucosa with slight changes in wall color or contents of the gastro intestinal tract (cecum); score 2 was moderate lesion characterized by more severe haemarrhage and a slightly thickening of the cecum wall; score 3 indicated severe haemarrhage with blood clots in the caeca lumen, and; a score of 4 indicated very severe lesions characterized by severe, widespread haemarrhages, blood clots in the lumen and bluish-red coloring of the caeca walls.

\section{Oocyst Excretion}

This examination was carried out daily on several birds. One gram of chicken feces or litter was suspended in $29 \mathrm{~mL}$ saturated salt solution. Then, the suspension was centrifuged at $1500 \mathrm{rpm}$ for 10 minutes. The supernatant was loaded into a McMaster's chamber and the number of oocyst was counted under a microscope at $400 \mathrm{x}$ magnification. The total number of oocysts in both boxes of the Mc Master chamber was counted and then divided by two. The average oocyst yield is multiplied by 200 to obtain the number of oocysts per gram of feces (Khaier et al. 2015).

\section{Body Weight Gain and Haematology}

Birds were weight daily from the day of infection until the day of necropsies. Examination of hemoglobin (Hb) was performed by Sahli method using Haemoglobinometer (Ogbe et al. 2010). Measurement of hematocrit values (packed cell volume, PCV) was performed according to previous method (Ogbe et al. 2010).

\section{Statistical Analysis}

A Completely Randomized Design with 7 treatments was used. Data on body weight gain and oocysts excretion were analyzed by analysis of variance (ANOVA) while the data of caeca lesions were analyzed using Kruskal Wallis. When significant differences in the means were found, the smallest real differences test was carried out. For the $\mathrm{Hb}$ and PCV, the values were analyzed descriptively by comparing values with normal reverence values.

\section{RESULTS AND DISCUSSION}

Artemisinin in A. аппиа is synthesized in the root and accumulated in leaves and other plant parts. Artemisinin content in leaves is the highest which may reaches $89 \%$ of the total content of plants (Laughlin 2002). Based on HPLC-UV analysis, (Drăgan et al. 2014) reported that A. апnиa leaf contained $0.75 \%$ artemisinin (Art), $0.18 \%$ dihydroartemisinic acid (DHAA) and $0.03 \%$ artemisinic acid (AA). The buds and flowers contained only $0.2 \%$ artemisinin (Art) and $0.3 \%$ dihydroartemisinic acid (DHAA) (Dragan et al. 2013). Brisibe et al. (2009) successfully identified bioactive compounds in $A$. annua as flavanoids, coumarins, steroids, phenolics, purines, lipids, aliphatic compounds, monoterpenoids, triterpenoids and sesquiterpenoids. In addition, A. аппиа leaves also 
contain many proteins, essential amino acids, minerals, vitamins and antioxidants. For this reason, synthetic artemisinin was included as control for the $A$. аппиа leaf extract.

\section{Clinical symptoms observation}

Chickens in the control group (PI - without infection) showed no sign of disease or abnormality. The infected groups showed panting (breathing rapidly through the mouth), lethargy, but their appatide seemed unaffected. Jatau et al. (2014) found that chickens infected with low doses of E. tenella show only mild clinical symptoms such as decreased activity and appetite and mild diarrhea.

Hematochezia or bllody stool was observed at fifth day after infection. This is in accordance to the observations of Jatau et al. (2014) which showed that generally a blood defectaion occured on the third or fifth day after infection of $E$. tenella but the the haemarrhage is short lasting. The condition is usually observed in mild infection of E. tenella which causes non-fatal, mild clinical symptoms. Ogbe et al. (2009) reported that the incidence of blood defecation in chickens infected with high-dose, 20000 oocysts of pathogenic strain occurred on the fifth day and followed by death if not treated.

\section{Excretion of Oocysts in Feces}

The appearence E. tenella oocysts in feces was first detected in five days after infection concurently with blood defecation. This result is in accordance with that of previous study which reported that E. tenella oocysts in feces were detected on the fifth post-infection (Drăgan et al. 2014). Furthermore, Jatau et al. (2014) also observed that the oocysts of E. tenella infection in different chicken strains (Marshal and Cobb) also showed the appearance of oocysts in feces on the day five after infection.

The excretion of E. tenella oocyst in the present study was principally similar to that of Pop et al. (2015), in which, oocyst excretion peaked at seventh day and waned on eighth day. In general, the peak excretion of E. tenella oocysts in infected chickens without treatment (PI) was higher than that in other treatments. However, the intensity of decrease in the oocyst excretion on the eighth day was not the same in all groups. The excretions of oocysts in chickens treated with the synthetic artemisin or $A$. апnиa extract were lower than that othe groups (P VI, Figure 1).

Observations on the eighth day showed that the decrease in E. tenella oocyst excretion had a negative correlation with the concentration of. The higher artemisinin concentration given the lower the oocysts excreted, decreasing from 58.14 to 23.55 - \% (Table 1). The decrease was lower than that reported by de Almeida et al. (2012), which was about $60-70 \%$ in chickens infected naturally with E. tenella.

The highest decrease in oocyst excretion $(74.18 \%)$ was in the infected chicken treated with A. апnиa leaf extract (Table 1). These results indicate that other compounds may enhance the activities of the artemisinin in in the extract of A. аппиа leaf. Infected chicken treated with comercial suphonamide decreased the oocysts excretion only by $50 \%$ (Table 1 ). However, the decrease in oocysts excretion after A. annua leaf extract treatment as found in this study was lower than that of Dragan et al. (2013) in which chickens infected with 1500 oocyst and treated with A. annua leaf powder reduced the number of oocysts in the feces by $87.9 \%$.The differences are might be to be due

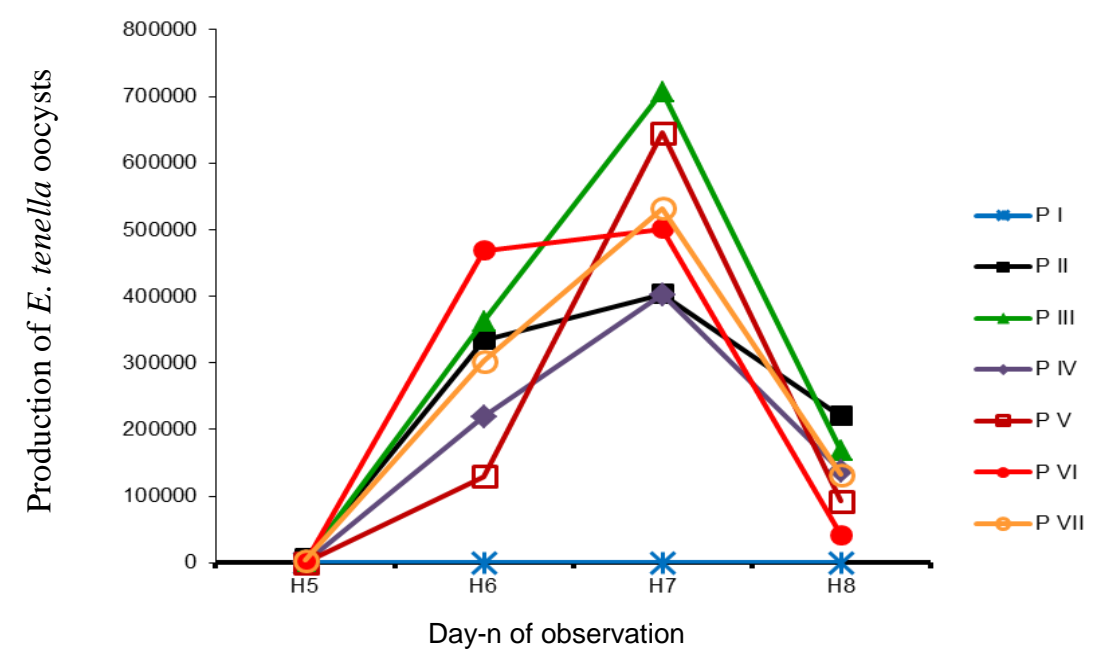

Figure 1. Excretion of oocysts in the feces of chicken five to eight days after E. tenella infection. 
to the variation in concentration of active compounds in the $A$. апnua leaf or differences in the pathogenicity $E$. tenella strain used.

The decraese in E. tenella oocysts in chicken feces after the administration of artemisin is also reported by del Cacho et al. (2010). A flow-cytometry analysis revealed that pure artemisinin $(99.5 \%)$ at $17 \mathrm{ppm}$ dose damaged the cell wall of oocysts as indicated by the uptake of propidium iodide resulting in the death or failure of the oocysts to sporulate. A significant decrease by $24.85 \%$ - $36.34 \%$ in spontaneous oocyst sporulation amount was observed. This finding may explain the decrease in the excretion of E. tenella oocysts found in feces (del Cacho et al. 2010).

\section{Chicken body weight}

The body weight gain of chicken is presented in Table 1 . The mean body weight gain between groups of chicken were not significantly different $(\mathrm{P}>0.05)$. This result indicates that treatment of chicken with artemisinin daily does not significantly affect body weight gain.

This result is in aggrement with Dragan et al. (2013) which compared weight gain $E$. tenella- infected chicken treated with powder of $A$. апnиa leaves, essential oli of A. annua leaves, Tween 80 and cocsidiostat (Lasalocid). The means of weight gain from the age of 7 - 35 days were not significantly different between treatments. As a matter of fact, chicken treated with $A$. апnиa leaf powder tended to decrease body weight on day 41. Engberg et al. (2012) demonstrated that chickens treated with hexane extract of $A$. апnua leaf at a concentration of $500 \mathrm{mg} / \mathrm{kg}$ of diet showed no significant body weight gain compared to control treatment.

de Almeida et al. (2012) also reported that there was no significant differences in mean weight gain between chickens fed with A. annua leaf and controls. Prior to infection with $E$. tenella, chickens fed with $A$. annua leaf mixture even had a lower body weight gain than controls. The study also showed that the chickens infected with E. tenella and treated with commercial anti coccidia sulfonamide had similar body weight gain as that in the group of chicken treated with A. апnиa leaf extract.

Several factors may explain those different results. There is a possibility of variation in the concentration of compound components contained in A. annua leaf due to differences in planting season, the differences in the methods of $A$. апnua leaf preparation, differences in research design, and differences in the susceptibility Eimeria species used against active compounds of $A$. annua (Drágan et al. 2010; Ferreira \& Luthria 2010). Furthermore, de Almeida et al. (2012) explained that artemisinin in A. annua causes a bitter taste in the diet leading to the decrease in chicken palatability. Therefore, there is a demand for additional natural ingredients that can reduce bitter taste in feeds such as Stevia rebaudiana leaves or molasses to increase chicken palabilaty that ultimately increases body weight and reduces the production of E. tenella oocysts (Kheirabadi et al. 2014).

Table 1. Body weight gain and inhibition oocysts excretion in chicken infected by E. tenella treated with artemisinin and A. annua leaf extract for eight days

\begin{tabular}{lcccc}
\hline \hline & \multicolumn{2}{c}{ Average body weight $(\mathrm{g}) \pm \mathrm{SE}$} & & $\begin{array}{c}\text { Inhibition of } \\
\text { oocysts excretion } \\
(\%)\end{array}$ \\
\cline { 2 - 4 } Treatment & Initial & End & Body weight gain $(\mathrm{g}) *$ & $381 \pm 22.67 ;-$ \\
P I & $426 \pm 9.27$ & $808 \pm 26.34$ & $316 \pm 39.06 ; 00.00$ & 0 \\
P II & $428 \pm 12.00$ & $744 \pm 34.87$ & $410 \pm 27.34 ; 29.75$ & 23.54 \\
P III & $450 \pm 20.25$ & $860 \pm 45.14$ & $368 \pm 62.40 ; 16.46$ & 37.5 \\
P IV & $426 \pm 42.38$ & $794 \pm 41.06$ & $458 \pm 27.82 ; 44.94$ & 58.14 \\
P V & $422 \pm 25.57$ & $880 \pm 24.29$ & $364 \pm 16.91 ; 15.19$ & 74.18 \\
P VI & $430 \pm 21.08$ & $794 \pm 24.82$ & $364 \pm 16.31 ; 15.19$ & 50.00 \\
P VII & $432 \pm 14.28$ & $797 \pm 21.35$ & & 5 \\
\hline
\end{tabular}

* Not significantly difference $(\mathrm{P}>0.05)$ 


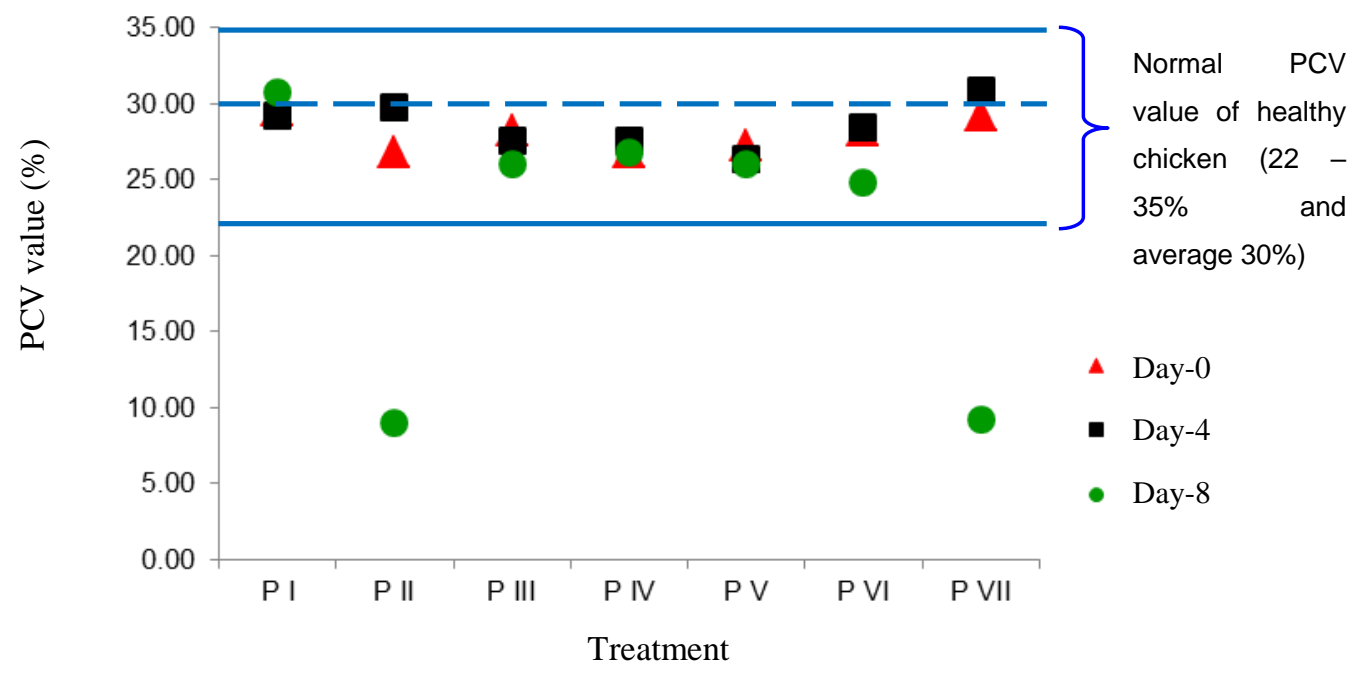

Figure 2. PCV value in chicken infected with E. tenella treated with artemisinin and A. annua leaf extract.

The unsignificant differences in mean body weight gain as observed in this study were also suspected to be influenced by infectious doses and E. tenella oocyst strains and chicken strains. Jatau et al. (2014) demonstrated two different responses between two chicken strains (Cobb and Marshal) against the infection of low doses of oocyst E. tenella (3000 oocysts). The average weight gain in Marshal chicken was not affected by low dose of E. tenella infection.

\section{PCV (hematocrit) value}

Generally, coccidiotic chickens are supposed to develop an anemia due to loss of red blood cell (Jatau et al. 2014). The PCV values on the 0 day of observation in this study showed normal values in all treatment groups $(26.20-29.60 \%)$. A significant decrease was found on the eighth day, where the PCV value of chickens infected with E. tenella without treatment (P II) and chickens infected with E. tenella with commercial product treatment (P VII) ranging from 9.00 to $9.20 \%$ (Figure 2). Compared to the control (PI), the average PCV value decreased in both group by 70 $70.8 \%$.

These results indicate that administration of synthetic artemisin and $A$. annua leaf extract for eight days was able to maintain PCV values from E. tenella infection. Similar results had been observed in previous studies (Jatau et al. 2014; Ogbe et al. 2010).

\section{Hb (haemaglobin) level}

The $\mathrm{Hb}$ level in four and eight days after infection of different groups of chicken are presented in Figure 3 .
In general, $\mathrm{Hb}$ levels in all treatment groups decreased from the fourth day to the eighth day, but the reduction was statistically insignificant $(\mathrm{P}>0.05)$ and still in the normal value for chicken, $9.00-11.50 \mathrm{~g} / \mathrm{dL}$.

\section{Phatology-anatomy observation of chicken cecum}

Pathologically, no lesion was found in the negative control group (PI). In the infected-untreated group ( $\mathrm{P}$ II), the lesion scored to 3.6 (severe tissue damage, thickening of mucosae, hemorrhage and calcification in wide areas). The infected-treated chicken group (P II - P VII) displayed less severe lesions, scored to 1.6-2.2. The changes include red spots or ptechia scattered in the caecal mucosa. Administration of synthetic artemisinin and A. апnиa leaf extract in chickens had an effect in preventing tissue damage (Table 2).

In this study, the percentage of scores of caecal damage in chicken treated with $A$. annua leaf extract (44\%) was lower than that in chicken treated with synthetic artemisin (61-72\%). However, it is more effective than that reported in a previous study. Dragan et al. $(2010,2014)$ reported a percentage score of $56 \%$ on low infection (1,500 ookista) and $56 \%$ in high infection (10,000 oocysts). Other study in chickens infected naturally with $E$. tenella and treated with powder and leaf essential oils of A. апnиa displayed caecal damage score of $58 \%$ and $68 \%$, respectivelly (Dragan et al. 2013). This mild caecal damage in the treatment group, presumably because the active compound of artemisinin has high antioxidant content and strong anti-inflammatory properties to inhibit $E$. tenella infection (del Cacho et al. 2010). 


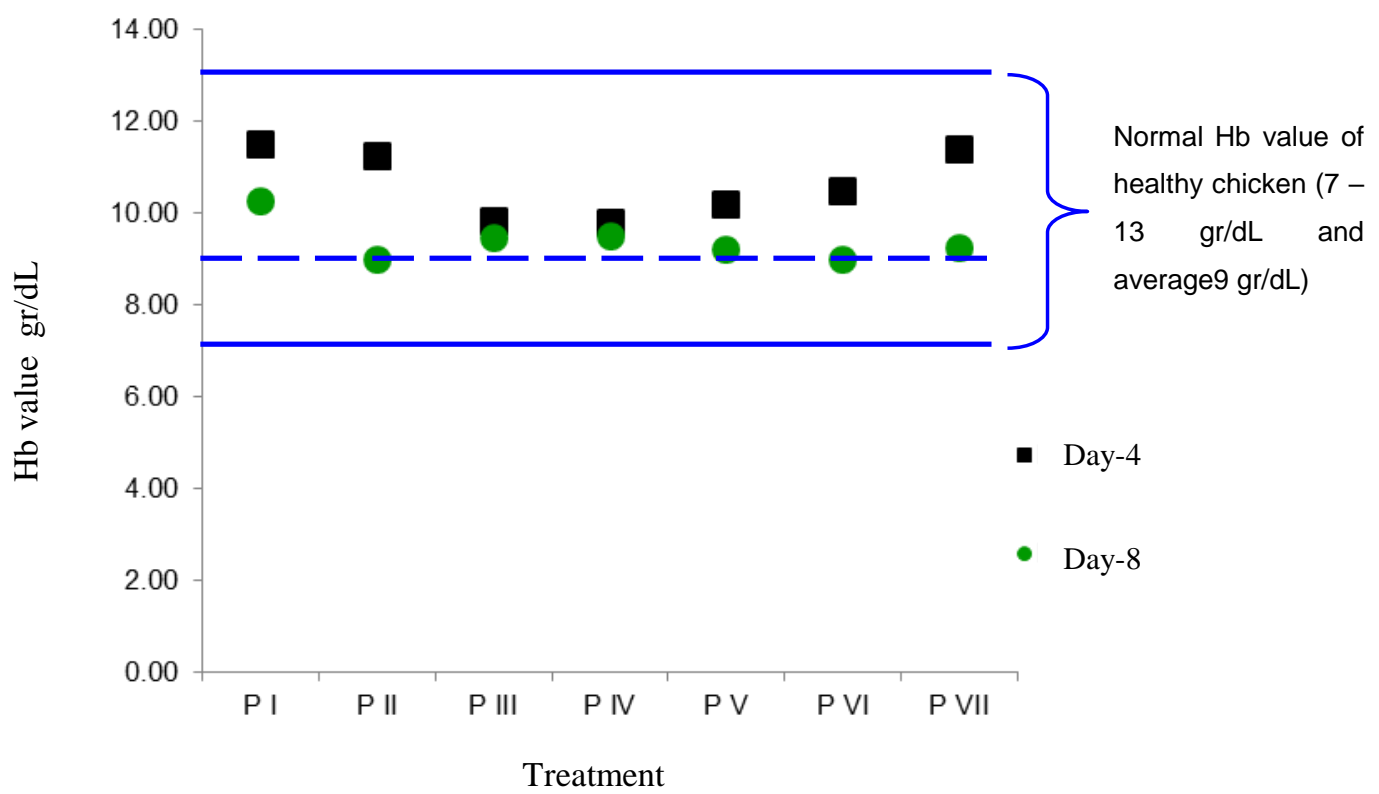

Figure 3. Hb value (gr/dL) in E. tenella-infected chicken treated with artemisinin and A. annua leaf extract.

\section{The mechanism of artemisinin against $E$. tenella}

There are at least two mechanisms of artemisinin compounds, directly at the developmental stage of parasites and indirectly through micro floral interactions in the digestive tract (de Almeida et al. 2012). The later is supposed to prevent activation of proinflammatory factor by the parasite and the body's immune response to E. tenella infection. Although administration of $A$. annua does not remove parasites completely, it may improve the immune system and resistance to infection, including lowering the risk of secondary bacteria infection. The anti-parasitic mechanisms of artemisinin compounds is hypothesed to be associated with the process of ookista wall formation resulting in the death of oocytes ultimately decreases the number of oocytes excretion (del Cacho et al. 2010). This mechanism involves inhibition expression of SERCA (sarco / endoplasmic reticulum calcium ATPase) in macrogametes that play an important role in calcium homeostasis. This disturbance inhibits the formation of oocytes walls which ultimately leads to oocytes death. Titilincu et al. (2008) demonstrated that suspension of oocytes on medium containing A. апnиa inhibit sporulation processes and damage sporulated oocytes.

Prevention and treatment of coccidiosis in chickens with artemisinin is relatively safe and does not affect weight gain, feed and water consumption as long as given at the right dose (Shahbazfar et al. 2011) According to Kheirabadi et al. (2014), artemisinin is relatively slow to absorb the body which is advantageous for treatment of coccidiosis. The slow absorption allows prolong interaction of the active compound with parasites in the digestive tract. Other advantage of applying artemisinin is its capacity to reduce oocytes contamination in the litter cage.

Table 2. Score of caecal lesion in E. tenella-infected chicken treated with artemisinin and A. annua leaf extract

\begin{tabular}{lccc}
\hline \hline Treatment & Lesion score & Average $*$ & $\%$ \\
\hline P I & $0,0,0,0,0$, & $0^{\text {a }}$ & 0 \\
P II & $+4,+4,+3,+3,+4$ & $3.6^{\mathrm{b}}$ & 100 \\
P III & $+3,+3,+3,+2,+1$ & $2.4^{\mathrm{c}}$ & 66.67 \\
P IV & $+3,+3,+2,+2,+1$ & $2.2^{\mathrm{c}}$ & 61.11 \\
P V & $+3,+2,+2,+2,+1$ & $2^{\mathrm{c}}$ & 55.55 \\
P VI & $+3,+2,+1,+1,+1$ & $1.6^{\mathrm{c}}$ & 44.44 \\
P VII & $+3,+3,+2,+2,+1$ & $2.2^{\mathrm{c}}$ & 61.11 \\
\hline
\end{tabular}

* Values with different superscript in the same column shows significantly difference $(\mathrm{P}<0.05)$

\section{CONCLUSION}

The A. аnпua leaf extract and synthetic Artemisinin are effective in reducing the severity of caecum lesion and depress oocyst excression in feces in chicken 
infected by E. tenella. Extract of A. annua leaf that contains artemisinin can be used as an alternative to commercial sulfonamides.

\section{ACKNOWLEDGEMENT}

The authors would to thank Indonesian Research Center for Veterinary Science for the financial support. Also to M. Dahlan, Opi Sajeli and Soedrajat for technical support during this research.

\section{REFERENCES}

Abbas RZ, Iqbal Z, Khan MN, Zafar MA, Zia MA. 2010 Anticoccidial activity of Curcuma longa L. in broilers. Brazilian Arch Biol Technol. 53:63-67.

Adamu N, Boonkaewwan C, Gongruttananun N, Vongpakorn M. 2013. Hematological, biochemical and histopathological changes caused by Coccidiosis in chickens. J Nat Sci. 47:238-246.

de Almeida GF, Horsted K, Thamsborg SM, Kyvsgaard NC, Ferreira JFS, Hermansen JE. 2012. Use of Artemisia annua as a natural coccidiostat in free-range broilers and its effects on infection dynamics and performance. Vet Parasitol. 186:178-187.

Arab HA, Rahbari S, Rassouli A, Moslemi MH, Khosravirad F. 2006. Determination of artemisinin in Artemisia sieberi and anticoccidial effects of the plant extract in broiler chickens. Trop Anim Health Prod. 38:497-503.

Aryanti, Ermayanti TM, Prinadi KI, Dewi RM. 2006. Uji daya antimalarial Artemesia spp. terhadap Plasmodim falciparum. Maj Farm Indones. 17:81-84.

Brisibe EA, Umoren UE, Brisibe F, Magalhäes PM, Ferreira JFS, Luthria D, Wu X, Prior RL. 2009. Nutritional characterisation and antioxidant capacity of different tissues of Artemisia annua L. Food Chem. 115:12401246.

Brisibe EA, Umoren UE, Owai PU, F B. 2008. Dietary inclusion of dried Artemesia annua leaves for management of coccidiosis and growth enhancement in chickens. African J Biotechnol. 7:4083-4092.

del Cacho E, Gallego M, Francesch M, Quílez J, SánchezAcedo C. 2010. Effect of artemisinin on oocyst wall formation and sporulation during Eimeria tenella infection. Parasitol Int. 59:506-511.

Cooper KK, Songer JG. 2009. Necrotic enteritis in chickens: A paradigm of enteric infection by Clostridium perfringens type A. Anaerobe. 15:55-60.

Dalloul R, Lillehoj HS. 2006. Poultry coccidiosis: recent advancements in control measures and vaccine development. Expert Rev Vaccines. 5:143-163.

Dragan L, Gyorke A, Ferreira JFS, Oprea O, Pop IA, Dragan M, Dan I, Pop L, Pastiu AI, Micrean V, et al. 2013. Performance and infection dynamics with Eimeria spp. in broilers medicated with Artemisia annua in comparison with laslocid and kept in field conditions. Lucr Stiint Med Vet. 46:51-62.

Drăgan L, Györke A, Ferreira JFS, Pop IA, Dunca I, Drăgan M, Mircean V, Dan I, Cozma V. 2014. Effects of Artemisia annua and Foeniculum vulgare on chickens highly infected with Eimeria tenella (Phylum Apicomplexa). Acta Vet Scand. 56:22.

Drágan L, Titilincu A, Dan I, Mircean V. 2010. Effects of Artemesia annua and Pimpinella anisum on Eimeria tenella (Phylum Apicomplexa) low infection in chickens. Sci Parasitol. 11:77-82.

El-Sadawy H, El-Khateeb RM, Kutkat MA. 2009. Preliminary in vitro trial on the efficacy of products of Xenorhabdus and Photorhabdus spp. On Eimeria oocyst. Blobal Vet. 3:489-494.

Engberg RM, Grevsen K, Ivarsen E, Fretté X, Christensen LP, Højberg O, Jensen BB, Canibe N. 2012. The effect of Artemisia annua on broiler performance, on intestinal microbiota and on the course of a Clostridium perfringens infection applying a necrotic enteritis disease model. Avian Pathol. 41:369-376.

Ferreira JF, Luthria DL. 2010. Drying Affects Artemisinin, Dihydroartemisinic Acid, Artemisinic Acid, and the Antioxidant Capacity of Artemisia annua L. Leaves. J Agric Food Chem. 58:1691-1698.

Ferreira JF, Peaden P, Keiser J. 2011. In vitro trematocidal effects of crude alcoholic extracts of Artemisia annua, A. absinthium, Asimina triloba, and Fumaria officinalis. Parasitol Res. 109:1585-1592.

Gholamrezaie SL, Mohammadi M, Jalali SJ, Abolghasemi SA, Roostaie AMM. 2013. Extract and leaf powder effects of Artemesia annua on performance, cellular and humoral immunity in broilers. Iran J Vet Res. 14:15-20.

Habibi H, Firouzii S, Nili H, Razavi M, Asadi SL, Daneshi S. 2016. Anticoccidial effects of herbal extracts on Eimeria tenella infection in broiler chickens: in vitro and in vivo study. J Parasit Dis. 40:401-407.

Jatau ID, Odika AN, Thlama M, Talba AM, Bisalla M, Musa IW. 2014. Response of 2 breeds of broiler chicks to experimental infection with low dose of Eimeria tenella sporulated oocysts. Turkish J Vet Sci. 38:398-404.

Jiang L, Zhao Q, Zhu S, Han H, Dong H, Huang B. 2012. Establishment of Eimeria tenella (local isolate) in chicken embryos. Parasite. 19:285-289.

Khaier MAM, Abdelhalim AI, Abukashawa SMA. 2015. Isolation and morphological identification of Eimeria tenella (Family: Eimeriidae) from Khartoum State (Sudan). J Appl Ind Sci. 3:177-181.

Kheirabadi KP, Katadj JK, Bahadoran S, da Silva JAT, Samani AD, Bashi MC. 2014. Comparison of the anticoccidial effect of granulated extract of Artemisia sieberi with monensin in experimental coccidiosis in broiler chickens. Exp Parasitol. 141:129-133. 
Laughlin JC. 2002. Post-harvesting drying treatment effects on antimalarial constituents of Artemesia annua L. In Bernanth J, editor. Proc Int Conf MAP Acta Hort. Tasmania (Australia); p. 315-320.

Lee JT, Broussard C, Fitz-Coy S, Burke P, Eckert NH, Stevens SM, Anderson PN, Anderson SM, Caldwell DJ. 2009. Evaluation of live oocyst vaccination or salinomycin for control of field-strain Eimeria challenge in broilers on two different feeding programs. J Appl Poult Res. 18:458-464.

Morris GM, Woods WG, Richards DG, Gasser RB. 2007. Investigating a persistent coccidiosis problem on a commercial broiler-breeder farm utilising PCR-coupled capillary electrophoresis. Parasitol Res. 101:583-589.

Ogbe AO, Atawodi, S E Abdu P, Oguntayo BO, Noel D. 2010. Oral treatment of Eimeria tenella -infected broilers using aqueous extract of wild mushroom (Ganoderma sp): effect on haematological parameters and histopathology lesions. Afr J Biotechnol. 9:89238927.

Ogbe AO, Atawodi SE, Abdu PA, Sannusi A, Itodo AE. 2009. Changes in weight gain, faecal oocyst count and packed cell volume of Eimeria tenella-infected broilers treated with a wild mushroom (Ganoderma lucidum) aqueous extract: article. J S Afr Vet Assoc. 80:97-102.
Pop L, Györke A, Tăbăran AF, Dumitrache MO, Kalmár Z, Magdaş C, Mircean V, Zagon D, Balea A, Cozma V. 2015. Effects of artemisinin in broiler chickens challenged with Eimeria acervulina, E. maxima and E. tenella in battery trials. Vet Parasitol. 214:264-271.

Shahbazfar AA, Mardjanmehr SH, Arab HA, Rassouli A, Abdollahi M. 2011. Effects of artemisinin in broiler chickens following chronic oral intake. Trop Anim Health Prod. 43:843-849.

Tabbu CR. 2006. Penyakit ayam dan penanggulangannya. Vol 2. Yogyakarta (Indones): Kanisius.

Titilincu A, Santha B, Cozma V. 2008. Effects of polioel 3 on sporulation and inefectivity of Eimeria oocysts. Lucr Stiint Med Vet. 41:372-378.

Tresnani G, Prastowo J, Nurcahyo W, Daryono. 2012. Profil protein stadium sporozoit Eimeria tenella isolat Yogyakarta melalui analisis protein SDS-PAGE. J Vet. 13.

Wiedosari E, Suhirman S, Sembiring BBR. 2014. Pengaruh jamu herbal sebagai antikoksidia pada ayam pedaging yang diinfeksi Eimeria tenella. J Penelit Tanam Ind. 20:9-16. 